\title{
3D printing technology as a method for discovering new creative opportunities for architecture and design
}

\author{
Linas Krūgelis, Vilnius Gediminas Technical University, Lithuania
}

\begin{abstract}
D printing technology has been in existence for several decades and has long been used exclusively for industrial manufacturing or product prototyping, and today this rapidly progressing technology penetrates more and more effectively into creativity fields. It encourages re-evaluation of the possibilities and methods that every person today can create, model, change their living environment. Opens up new possibilities for customized architectural and product design. The world-wide technological experiments provide new and still untapped tools for future developers.

The article analyzes the current situation of recent decade in the Western world regarding the use of threedimensional (3D) press in relation to the living environment. The study highlights emerging trends and new opportunities for creativity for architects and designers. From printing complex geometrical structures to practical application in product design. The research analyzes the research of different authors, and some significant technological innovations. All this makes it possible to concentrate and effectively evaluate the direction of the development of this industry and the expected result for the future development of architecture in contemporary digital age. Since 3D printing in architecture and landscape design is not yet widely used, the article discusses the most recent experiments conducted by various researchers in recent years, reflecting the trends of the fourth industrial revolution and which can influence further architectural development.

The research methodology is based on historical research, analogical descriptive and comparative methods. The results of the research suggest that, as the 3d printing technology grows and develops, architecture and the design of the environment will acquire a wider variety of artistic expression.
\end{abstract}

Keywords: Contemporary architecture, industrial design, 3D printing, Contemporary art

Technological trends

Three-dimensional Originally, this type of manuf in the field of industrial production, where the advantages of this technology were revealed. Since then, production has been classified into two main directions. The first is subtractive (from English - to subtract), which is the traditional way of machinemaking, when obtaining a product from a raw material by drilling, cutting, milling, turning, etc. The second method is called additive (from English - to add), when the material is used as much as it is needed. Prior to the emergence of 3DP, this production technique was represented by various products made by casting - reinforced concrete, plaster items, etc. However, additive 3DP has also moved on to the creation of a real-life residential environment. The ability to quickly create prototype items based on pre-existing digital information models has significantly accelerated the creative process of developing industrial products. Moreover, a new paradigm on the production of goods started to emerge in all modern industrial production. Jeremy Rifkin, US Economics and Sociology theorist, in the year 2012 argued that 3DP will bring about such changes in the industry in the near future, which could be compared to the Third Industrial Revolution [1].
Architect Michael Hansmeyer also considers an add-on production as a future inevitability in architecture and design. According to him, "the potential of additive production in architecture is enormous. Architectural details (transmitted by this technology) can reach the limits of human perception. The complexity of the forms in this case is no longer a cost determining factor, since printing of the complex forms of the object costs as much as printing a primitive cube. <...> Ornaments (of this kind) are no longer a luxury feature, and three-dimensional printing will legitimize them again (Grotesque)".

Aaron Silver of the Softkill Design team says that 3DP can lead to cheaper building construction with using less material. In his view, saving money, material efficiency - these are the matters that are most relevant to architects [2].

According to J. Rifkin, five industry performance advancing criteria are needed in order for the industry to move in the following revolution: (1) Transition to renewable energy; (2) Providing energy generation function in each building; (3) Installing autonomous tanks of hydrogen and other fuels in buildings as prevention of interruptions in energy supply; (4) Creation of a global interconnecting energy sharing network, where consumers who generate excess energy could transmit energy to consumers in need; 
(5) Shifting transportation to electricity or fuel cell vehicles. These infrastructure components, according to Rifkin, should be embraced by a global data network connecting residential houses, businesses, cars, and household appliances [2].

Technology analysts are seeing the beginnings of these processes today. With the advance of 3DP technology, the foundations of "Internet of things" are being formed. It is not only electronic communication between devices, but also intellectual information about the same things, their virtual models. Using 3DP, the required item can be printed using the purchased digital model. This principle saves not only time but also transportation costs and ensures that the necessary items are produced to the extent that they are needed by their consumers.

3DP popularity among home users has been driven by the well-known RepRap project, when 3D printers are purchased as a set of components that are easy to assemble at home. And some details can be multiplied by the same 3DP method. The cost of this type of equipment has become affordable to many home users in recent years. This has resulted in the availability of ready-to-print models on specialized web portals such as Thingiverse or Cubify. Moreover, this area is also being promoted by users actively engaged in social networking environments.

All this, as predicted by Rifkin, opens up new opportunities for people to express themselves in a creative way. The real environment in the living space can be developed in a more user-friendly way, when the user can create the things he needs using the CAD software himself or by using the readymade digital models to materialize them with 3DP [3]. Therefore, this article will focus on what tendencies unfold in the fast-growing 3DP technology to create elements of the human residential environment.

Timothy Wolf, an explorer of 3D trends in the United States, points out that this technology can also have a devastating effect on the industry. In the book "3Dd Printing Industry - Concise Guide: Technologies, Markets, and Players" this author claims that 3DP will respond to the job market in industry, reduce the need for staff in the field of prototyping, and competition among companies will be decided by successes of smaller numbers of employees who are more knowledgeable about technology and innovation. According to Wolf, the market should become more dynamic, more engaging social networks [4].

In the recent years, technology science has increasingly been discussing the true 3DP perspectives for creating spatial objects. This technology is promised a brilliant future, but it is much more important to explore and evaluate what achievements are already reached. This, in its turn, can help reveal further guidelines for the development and efficient use of technology. Only with proper knowledge and development of promising areas based on 3DP, long-term intellectual and material benefits to science and industry can be expected.

This article discusses the three emerging trends of 3DP technology, that are identified by analyzing the sources of research, and are based on the academic practice of the author of this text at the Vilnius Gediminas Technical University. These typological directions consist of: experimental and applied research of materials; studies of reproduction of calculated volumes and spaces; multi-purpose functional adaptation experiments.

It is important to discuss each of these areas in more detail. These three areas include architectural, landscape, and object design scopes and complement each other. This text does not cover those threedimensional printing areas that are not related to the formation of the residential environment and its aesthetic qualities.

\section{Experimental and applied research of materials}

The progress of 3D printing technology in both industry and home use is supported by the growing supply of new printing materials on the market. It has long been known for the possibility of printing things from plastic beads, various metal powders, etc. Items printed from these materials are used in many areas of life: industrial production, design, architecture, medicine, robotics, mechanotronics, etc. Small consumers which have so far traditionally been using ABS (acrylo-nitrile-butadiene-styrene) or PLA (Poly-lactide) type thermoplastic fillers, can already create wood-like plastic material that contains genuine wood pulp and also can use various elastic, rubber or silicone-like fillers, such as TPE (thermoplastic elastomer), etc. It expands the ability of individual consumers to successfully realize creative intentions, ideas, and to test them functionally. As a result, for the 3D printing users it has become popular to develop and print various, small prototype elements of the environment.

Along with this, there is a number of significant researches and experiments designed to detect 3D printing capabilities with non-traditional materials for this technology, in order to expand there the usability of the 3D print. An excellent example of this is the British study of the use of ceramic filler in 3D printing. Researchers at the University of West England (UWE) prof. Stephen Hoskins, along with doctoral student David Huson, have carried out research in 2012-2015, in which they sought to replicate the technique of Egyptian faience (kind of ceramic production) with $3 \mathrm{D}$ press. According to the researchers, it is possible to create a modern, 


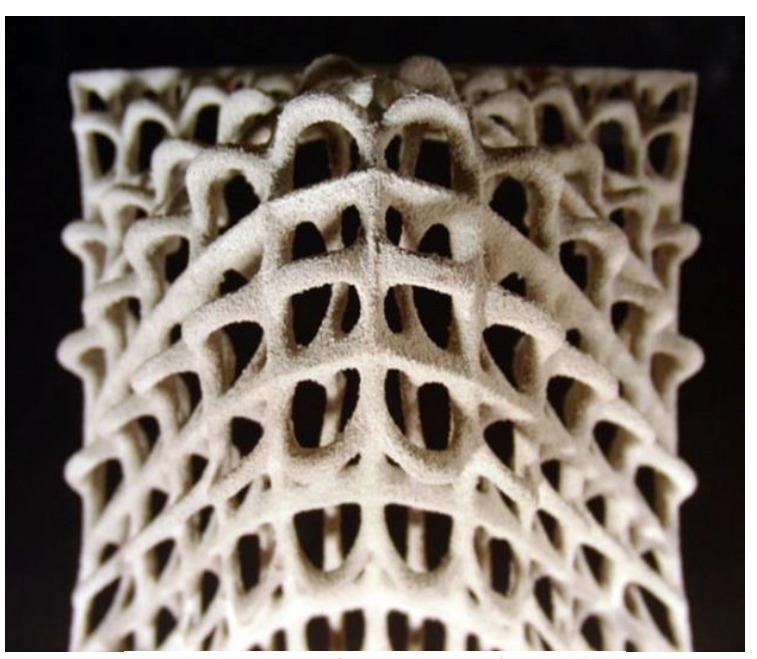

Fig. 1. $3 D$ printed ceramic products, 2008. Source 10.07.2018.

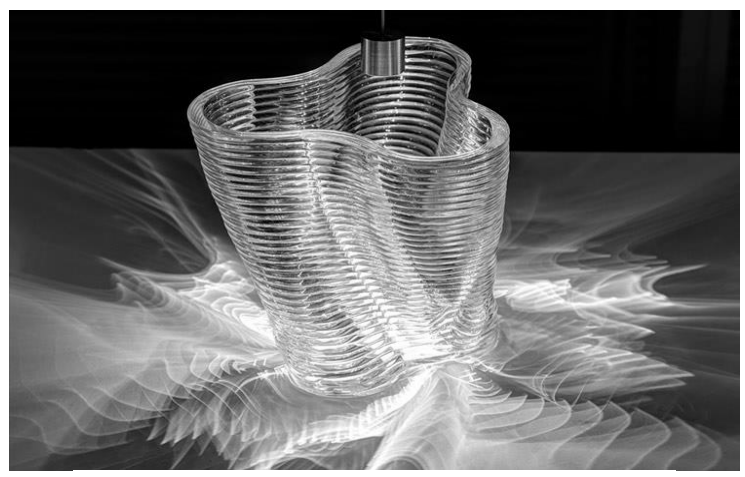

Fig. 2. Lighting efects of 3D printed glass structure, Neri Oxman (MIT Media Lab, 2015 m.)

Source: http://robotika.lt/pirmasis-3d-spausdintuvas-kuriuogalima-gaminti-stiklo-dirbinius-video/ [accessed 11.07.2018].

print-suitable, glossy (self-glazed) ceramic material that would look like the Egyptian faience by its appearance and quality [5].

Even more spectacular results could be achieved with many other natural materials together with usage of sophisticated CAD software. Some extraordinary examples are displayed in a book Earth Architecture (Princeton Architectural Press 2008). It presents the most widely used building material on the planet-earth (soil, clay, gravel and sand) - as relevant to contemporary and modern architecture and dissolves preconceptions that it is a fragile material in use only in poorer, developing nations (Fig. 1) [6].

The validity of the goals set by these investigators is demonstrated by the fact that in 2011-2012, the team of the same researchers, led by S. Hoskins in partnership with Denby Pottery, have developed and patented 3D printing technology for ceramics, where a printed product can be burned and glazed at once [7]. Earlier in 2010 researchers at UWE University, Peter Walters, together with Jonathan Rossiter and Ioannis Ieropoulos, received funding for $3 \mathrm{D}$ research on prestigious materials. In the course of the study, the applications of materials that are sensitive to contact with other external stimuli, for use in 3D printing were investigated. The use of such materials is possible in interactive and robotic design areas and in many other engineering, design or contemporary arts areas [8].

3D printing using ceramic fillers has a wide range of applications in architecture. This trend is illustrated by the presentation "Data Clay: Digital Strategies for Parsing the Earth" at the San Francisco Museum of Crafts and Design (2015). A large group of researchers and practitioners experimenting with digital technologies and their applications in ceramics gathered here [9]. The use of clay for the three-dimensional printing poses a significant challenge, because it is difficult to control the shrinkage of this material by drying or deflation at a soft consistency. Nevertheless, the exposition contains a large number of high artistic quality ceramic products. Mostly modular interior decoration solutions, paved interior, decorative interior partitions, ceiling decoration solutions, etc., are displayed.

As for other traditional materials that can be used in the 3DP, perhaps the most worthy of attention are the MIT (Massachusetts Institute of Technology) experiments on hot-glass 3D printing. In a pilot project led by Neri Oxman, the scientist of the Institute, there the right technological conditions for the use of glass as a printing material were successfully created. When heated up to more than one thousand degrees Celsius, the glass has gained a tonic, honey-like consistency. This allowed the use of additional robotic equipment to form spatial objects from a liquid glass jet. Compared with the traditional glass blowing technique, the printed glass objects were geometrically more precise, with a distinctive surface texture both on the outside and inside of the object. With use of the light, a highly diffractive light diffraction effect has been observed that is not typical of traditional glass products [10]. This glass printing technology has potential in the field of architecture, interior design and the design of objects. The interaction of spatial forms and reflections of light would allow the appearance of new decorative solutions in a real environment (Fig. 2). Moreover, in some cases this method of production would allow for tailor-made, individualized solutions.

Researchers of "LinkMenų fabrikas" in Vilnius Gediminas Technical University (VGTU), in cooperation with their partners, in year 2017 have carried out a different 3DP experiment. The aim was to test and demonstrate the advanced 3DP and 3D scanning technology capabilities. The idea of creating a very small copy of the Biblical Crib, reproduced by 3DP methods, was set forth in order to meet the coming yearly feasting period. The 
project participants have created the world's smallest nano-crib, which has already been presented to the Guinness World Records book. The implementation of the idea of the nano-crib lasted for three months, with the team of 30 people working-VGTU students and scientists, researchers of the VU Laser Research Center and UAB "Femtika" and 3D technology company UAB "Idea 3D". The size of the nano-crib is just 300 micrometers $(0.3 \mathrm{~mm})$. The entire crib patch is easy to fit on the eyelash, and the smallest printed figure of the baby Jesus is smaller than the human cell [11]. Although this project was focused on the prospect of popularizing technology in society, it also illustrates the broad perspectives of 3DP application in a practical environment.

\section{Research of computational architecture and space}

Architectural theoretical and practical studies are increasingly exploring the more and more diverse 3DP applications in architectural creativity. The imagination of researchers inspires not only the development of shapes, but also the constructive perspectives of the metal, allowing the creation of extremely sophisticated, complex forms, volumes and surfaces. They are assisted by advanced software and hardware. Quite often, artificial intelligence is also being discussed in the development of urban space. Conveying digital data, models in tangible form, enables realization of objects with mathematical accuracy.

This is well illustrated by the Swiss-based "DigitalGrotesque" team of architects Michael Hansmeyer and Benjamin Dillenburger. Interestingly, the fact is that the developers call themselves architects - programmers. The creative direction of this collective is directly linked to the development of architectural forms based on mathematical fractal algorithms. The main goals of their analytical work are to create architectural solutions that reject the usual criteria for classification and typological reduction; explore new, unseen surfaces and geometric forms of digitization, topological analysis methods [12]. In their projects, the authors use special algorithms for mathematical analysis and geometric transformation. The shapecreation process itself balances subtleties between controlled and random forms of transformation. The applied simulation algorithms are deterministic on the one hand, and on the other hand the results are not always predictable. The most famous work of this group of creators is the Spatial Installation "Printing Architecture" (Fig. 3). In this project, the architects have modelled an extremely complex interior design of a small space installation. It's a kind of gypsum cube, with complex reliefs based on the negative principle of terrain carving, but in fact it is a composition of futuristic architectural elements produced by powder 3D printing technology.

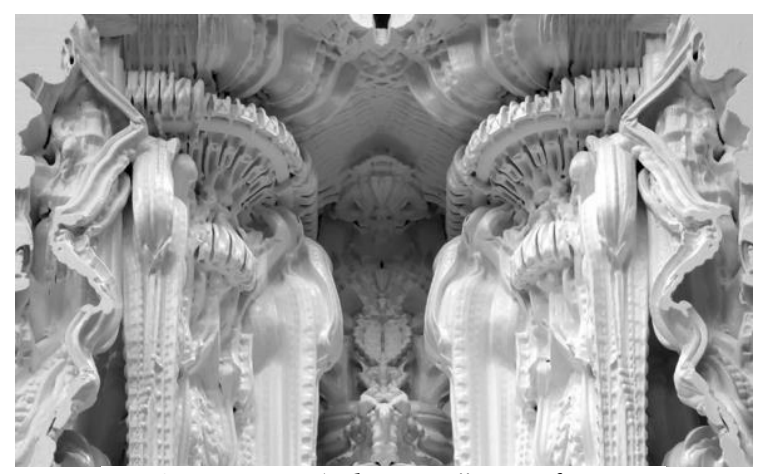

Fig. 3. „Printing Architecture” space fragment, archit.: Michael Hansmeyer, Benjamin Dillenburger (Digital Grotesque, Switzerland, 2013)

Source: https://inhabitat.com/digital-grotesque-architectureduo-set-to-unveil-entirely-3d-printed-room-next-month/ [accessed 11.07.2017].

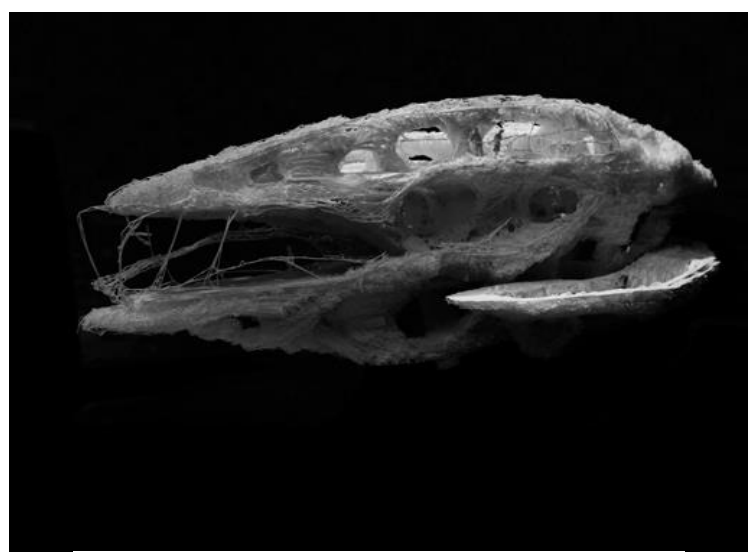

Fig. 4. ProtoHouse 2.0 - First 3D Printed Dwelling by Softkill Design, London, 2012.

Source: https://www.treehugger.com/greenarchitecture/softkill-design-joins-race-build-first-3d-printedhouse.html/ [accessed 05.07.2017]..

The plasticity of the forms reflects the architectural decoration of the Baroque period with the intense surface partitions, but here we do not see illustrations of the usual objects or forms, and only the realization of a purely synthetic, digital form is shown. However, this is enough to make the observer become space compelled or even enticed. The installation was created by printing $120 \times 120 \mathrm{~cm}$ blocks and combining them into a single composition.

The conceptual, 3DP-based architecture topics are considered also by a team of architects from London, named Softkill Design. Their built-in home concept, "ProtoHouse 2.0", is based on the principle of printable and installable components (Fig. 4). This architectural work is designed as a selfattaching agglomeration, linking to the natural landscape or to already existing buildings. It embodies some of the concepts of bio-mimetics that are popular nowadays, such as the notion that nature creates its own architecture by developing an organic form. It is emphasized therefore, that the 


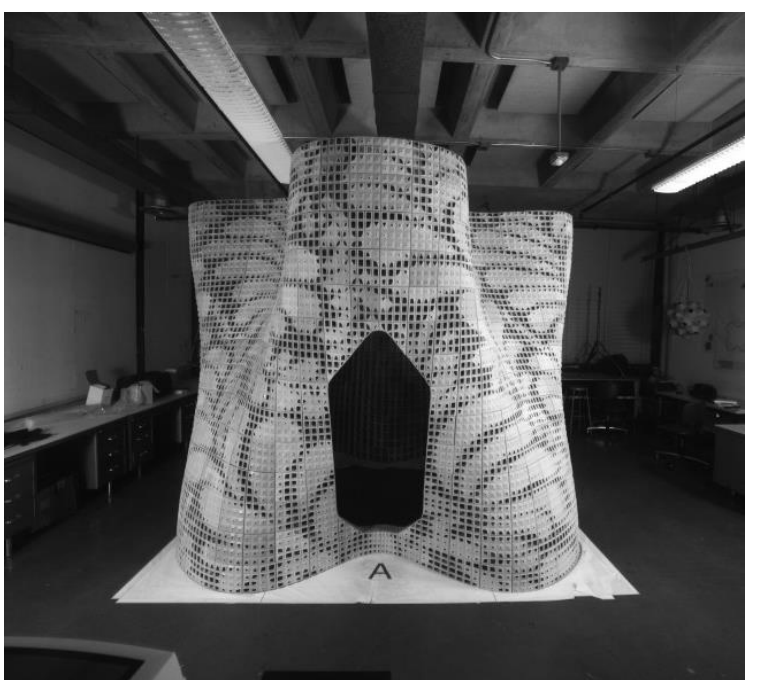

Fig. 5. U.C. Berkeley Researchers 3D Print a CementPowder Pavilion. USA. 2015.

Source: https://www.architectmagazine.com/technology/ucberkeley-researchers-3d-print-a-cement-powder-pavilion_o/ [accessed 05.07.2017].

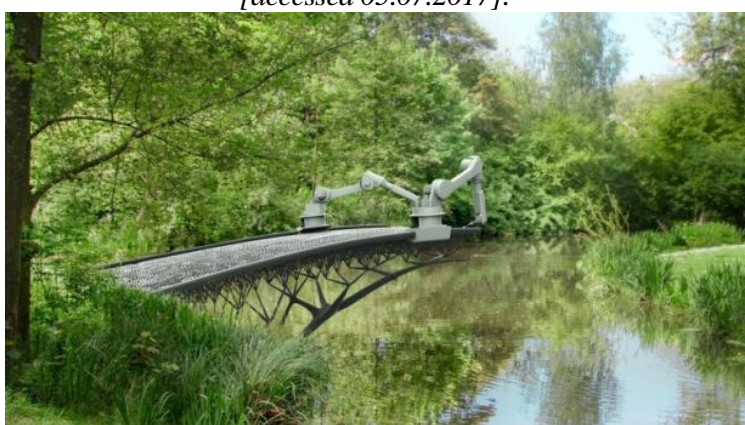

Fig. 6. 3D printed pedestrian bridge. Amsterdam. 2016. Source: https://www.popsci.com/bridge-printer/ [accessed 05.07.2017].

straight lines of things are alien to the natural environment. The authors of this project used a numerical algorithm that simulates the natural mechanism of growth of bone structure in nature [2]. The volume is created not as a full bubble filling, but rather as a weave of individual structural strands, merging into one spatial network. In this way, a light weight but robust architectural structure is created. The silhouette of the object resembles a skull of prehistoric lizard. The purpose of this conceptual model was to explore the possibilities of threedimensional printing in accordance with the SLS (Selective Laser Sintering) technology with highlevel spatial structures. Developers predict that in the future, using this technology, it will be possible to print the buildings in one day [13]. On the other hand, it has to be admitted that this concept is still in the form of a reduced model; it seems that the researchers have not performed yet the real-scale tests.

The printing of architectural objects or their parts from concrete or various other experimental fillings is increasingly popular in the three-dimensional printing industry. For example, the University of
California-based Environmental Design College (Berkeley) students developed an experimental pavilion, called "Bloom", using 3DP technology and cement powder (Fig. 5). It is a freestanding, portable, spatial structure with a height of about $2.7 \mathrm{~m}$. It consists of 840 printed interconnected blocks, made of non-ferrous oxide cementitious polymer. Therefore, this material is lighter than the conventional cement. The whole structure of the pavilion is supported by a stainless steel frame and the latter is supported by printed components of the building. According to the authors of the project, this architectural structure is by far the largest printed architectural area of this kind [14]. When designing this pavilion, the young architects have set the task of using a realistic, able to withstand in the market conditions constructional process. In their opinion, this should change the attitude of people towards the tectonic construction of conventional buildings. "Bloom" pavilion's shell is made of a uniform shape, with the upper edge of the volume being rotated 45 degrees. This form of plastic makes it possible to create light play in the interior space. The architectural expression of the object is inspired by the famous Uruguayan architect Eladio Dieste impressive masonry architecture, and one can also see the features of Richard Serra "Torqed Ellipse" [14].

3DP technology has been applied in the field of landscape architecture in recent years. Even in several parts of the world, real-scale testing is being made to build bridges for pedestrians. First considerable achievement in this field has been obtained by Spanish scientists from the Institute of Advanced Architecture of Catalonia (IAAC). There was created the $12 \mathrm{~m}$ long and $1.75 \mathrm{~m}$ wide pedestrian bridge, printed on robotized machines using micro-reinforced concrete [15]. The proportions and the plastic expression of this bridge form raises a lot of doubts, but considering the fact that it is the first object implemented, this in itself can be regarded as a significant achievement by the developers.

Nevertheless, in recent years, the focus of the architectural community has been fixed on the prototype of the Dutch starter MX3D's pedestrian bridge over the Amsterdam Canal (Fig. 6). The latter promises a big breakthrough both in artistic and technological terms. The bridge printers are moving on their own printed designs, so designers Joris Laarman and Tim Geurtjens have designed an organic-shaped bridge frame structure that is printed out of metal with the help of an industrial six-axis robot and metal-welding equipment [21]. The construction of the pedestrian bridge is expected to be completed in 2019 .

These and other 3DP technology-based projects show that, in the very near future, environmental 
design and architecture will acquire new forms of expression that are closer to nature. And at the same time, it will allow to save more resources.

\section{Multifunctional 3DP use in residential space}

Since its very outset, 3DP has been focused on meeting the needs of a wide range of people, and it is not surprising that the growing popularity of this technology makes printing products change the human environment or even the entire genesis of contemporary realm of tangible environment. Sometimes this technology offers revolutionary furniture or decoration solutions, but sometimes even simple 3D products are enough to open up new possibilities to create things.

One example of this is the series of universal plastic connections made by the Hungarian designer Ollé Gellért. They are designed to form furniture (shelves) from glued laminated sheets by interconnecting them. These connectors can be printed in a 3D printer at home (Fig. 7). By using elements of the various configuration connections, it is possible to create both regular and irregular-type shelves. The authors of the idea at the project presentation demonstrate the products printed in the SLS way, when the form is obtained by selectively hardening the special printing powders. The details have a plastic shape and a smooth surface, making the structure of the modeling furniture an extra tectonic impression. In developing this design solution, Gellért sought to give the consumer the opportunity to create and experiment with furniture design [16].

Similarly, the furniture connector design was developed by Minale-Maeda design bureau in Milan. In this case, the plastic hinge joins the table legs and the transverse structures with each other. In this way, the furniture item can be constructed using wooden bars of any suitable cross-section area and the chosen table-top board. The structural strength of printed joints is sufficient to withstand typical table loads. The designed connector module allows to create tables of various sizes and configurations [17].

In the area of 3D-printed furniture, it's important to mention Janne Kyttanen, one of Finland's bestknown enthusiasts in this field. He presents himself as a digital sculptor, whose work combines $3 \mathrm{D}$ printing and the synthesis of virtual or expanded reality. The works of this designer are characterized by sculpture and expressed tectonics. One of his latest works is the dynamic shape "Metsidian" table, developed using 3D printing and explosive welding techniques. Working with this method involves the use of explosives that help to blend materials that cannot be combined with traditional welding techniques [18]. In this way, Kyttanen has combined a metal with a volcanic rock. Another piece of the

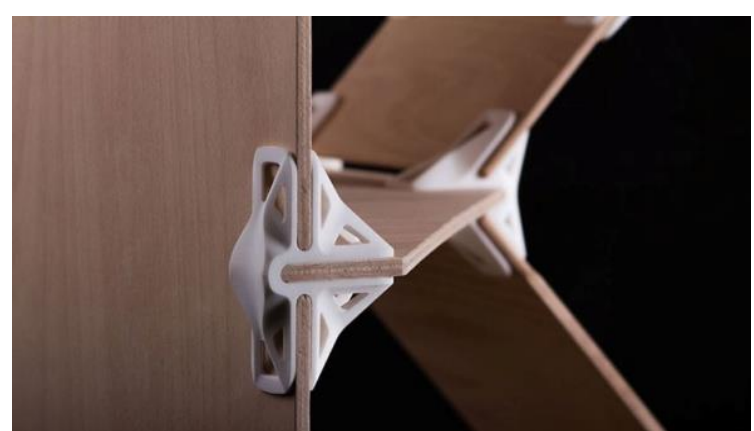

Fig. 7. 3D printed furniture joints by designer Ollé Gellért, 2015.

Source: https://www.designboom.com/technology/olle-gellert3d-printed-joints-07-29-2015/[accessed 07.07.2017].

work of this creator - a metal network couch leaves no less impression. The industrial 3D metal printing technology is also used here. The design of this furniture has been developed by the designer on the basis of naturally occurring cobweb or silkcocoon weaving patterns [19].

\section{Multiple use of $3 D$ printing in the context of contemporary living area}

Formerly discussed 3DP application examples only reflect a small part of trend, how fast this technology penetrates into the field of design and architecture. Undoubtedly, this is a positive phenomenon that allows us to go beyond the usual constraints of manufacturing processes, while helping to rationalize the production of materials. Nevertheless, there are factors limiting the popularity of 3DP technology. The biggest of them is the lack of knowledge and skills in working with CAD programs. Only those who are capable of creating virtual models of future items will be able to fully and effectively use the benefits of 3DP technology. In Australia, New Zealand and some European countries, 3D lessons are already included in curricula [20]. So far, it has been assumed that the work of 3D computer simulation programs is only required for those seeking engineering education. Such a provision is no longer correct, as 3DP technology encompasses an ever wider range of users, and it is therefore necessary to take this into account when refining and updating school curricula. The basics of computer 3D simulation should be made part of basic computer literacy.

Looking at Lithuania's context, Vilnius Gediminas Technical University was one of the first in Lithuania to promote active 3DP technology at various stages of education levels. The various nonformal education partnerships with secondary schools provide practical training sessions for the promotion of mathematics, natural sciences and technology (STEM). Students learn about 3D modelling and 3DP. The experience of recent years has shown that such classes significantly 
increase students' interest in engineering and technological sciences.

More intensively 3DP is being used to implement engineering study programs. Hence, students of the Industrial Design study program begin to deepen their knowledge of computer simulation (CAD) from the very first semester in the Solidworks program. It is highly rated on the job market. Already after the first semester, the basic skills of using this program are acquired, and they are developed further during all studies. For several years now, using this practice, it has been noticed that early implementation of CAD knowledge not only positively motivates students to learn. It also enables them to deal with more complex design and engineering tasks. Moreover, by including 3DP-based product prototyping into the process, better performance efficiency and time planning indicators are obtainable.

\section{Conclusions}

1. The rapid expansion of three-dimensional printing technology shows that in the future understanding of the creation of things will change cardinally the design process. Work with materials will more and more shift to work with data and information. And the comprehensive rapid data sharing with the help of the Internet will allow even faster development of future products, with especially low financial and time costs.

2. The advantages of the additive production before the subtractive one, that are being observed today, make it possible to predict that in the near future the share of additive production in local Western European manufacturing industries will grow. However, this growth requires several conditions, namely: (1) Innovative data creation, transmission and legal protection measures; (2) Targeted education and training in the educational institutions of specialists capable of operating 3D modelling and prototyping; (3) Consumer education and encouraging them in the field of new technologies.

3. The use of new materials in the field of $3 \mathrm{D}$ printing undoubtedly contributes to the popularization of these technologies among professional and as well as at home users. Examples of analysis have shown that 3D printing can carry out extremely complex and high-precision jobs such as ceramic printing, furniture components and interior design. This is how it approaches the practice of home-made things.

4. Architecture in this era of technology transformation also reveals new realization areas. The use of 3DP in construction would not only significantly alter the process and duration of construction works, but would also significantly affect the thinking of architects in designing such type buildings. Such construction would save a lot of money, as there would be no need to use a large number of different equipment. Material costs would be significantly lower, as it can evidently be expected in case of additive production.

\section{References}

1. Rifkin, J. The Industrial Revolution Powered by oil and other fossil fuels, is inspirating into a dangerous endgame [online 15.01.2016]. http://www.thethirdindustrialrevolution.com/

2. Blakeway, A. M. Experiments with $3 D$ prnting technologies ir masonry constructions: Bachelor thesis. Massachusetts Institute of Technology, 2016. $11 \mathrm{p}$. [online 18.06.2017]. https://dspace.mit.edu/ bitstream/handle/1721.1/103493/952418987-MIT.pdf?sequence=1

3. Rifkin, J. The Zero Marginal Cost Society. New York: St. Martin's Press, 2014, p. 5.

4. Wolf, T. 3D Printing Industry - Concise Guide: Technologies, Markets, and Players. CreateSpace Independent Publishing Platform, 2014, p. 8.

5. Huson, D., Vaughan, K., 2015. 3D printed self-glazing ceramics: Process and materials development. NIP \& Digital Fabrication Conference, 2015 (1), p. 416-420. [available at:] http://eprints.uwe.ac.uk/25857

6. Digital ceramics [online 10.07.2018]. http://www.rael-sanfratello.com/?p=804

7. Solid free-form fabrication in fired ceramic as a design aid for concept modelling in the ceramic industry (project duration 31.03.2011-30.03.2012). Center of Fine Arts Research. [online 15.01.2016]. http://www.uwe.ac.uk/sca/research/cfpr/research/3D/research_projects/solid_free_form.html

8. Smart materials and novel actuators: Creative applications in art and design (project duration: 01.02.201031.10.2010). Center of Fine Arts Research. [online 16.03.2016.]. http://www.uwe.ac.uk/ sca/research/cfpr/research/3D/research_projects/smart_materials_novel_actuators.html>

9. Shaw, M. Are 3D-Printed Ceramics the Future of Architecture? Architizer [online 01.15.2016]. http://architizer.com/blog/data-clay/

10. Klein, J., Stern, M., Franchin, G., et al. Additive manufacturing of Optically Transparent Glass. 3DPrinting and Additive Manufacturing, 2015, Vol. 2(3), p. 92-105. https://doi.org/10.1089/3dp.2015.29001.sti

11. Lietuvoje sukurta mažiausia pasaulyje prakartėlè [online 5.02.2018]. https://www.vgtu.lt/vgtu-naujienuportalas/naujienos/lietuvoje-sukurta-maziausia-pasaulyje-prakartele/246059?nid=290713

12. Dillenburger B., Hansmeyer M. The Resolution of Architecture in the Digital Age. In: Zhang J., Sun C. (eds.) Global Design and Local Materialization. CAAD Futures 2013. Communications in Computer and Information Science, Vol. 369. Springer, Berlin, Heidelberg, 2013. 
13. Bojovic, M. ProtoHouse 2.0 - First 3D Printed Dwelling by Softkill Design [online 15. 01.2016.]. http://www.evolo.us/architecture/protohouse-2-0-first-3d-printed-dwelling-by-softkill-design-london/

14. Busta, H. U.C. Berkeley Researchers 3D Print a Cement-Powder Pavilion [online 16.01.2016]. http://www.architectmagazine.com/technology/uc-berkeley-researchers-3d-print-a-cement-powder-pavilion_o

15. The Institute for Advanced Architecture of Catalonia designs the first $3 D$ printed bridge in the world [online 15.01.2018.]. https://iaac.net/institute-advanced-architecture-catalonia-designs-first-3d-printed-bridge-world/

16. Print to Build 3D printed joint collection by Ollé Gellért [online 20.01.2018]. http://retaildesignblog.net/2015/08/02/print-to-build-3d-printed-joint-collection-by-olle-gellert/

17. Kohlstedt, K. 3D-Printable Connectors Make DIY Furniture Assembly Easy [online 15.01.2016]. https://weburbanist.com/2014/04/22/3d-printable-connectors-make-diy-furniture-assembly-easy/

18. Tucker, E. Janne Kyttanen unveils metal and volcanic-stone table made with exlosion welding [online 18.01.2016]. http://www.dezeen.com/2015/12/02/janne-kyttanen-unveils-metal-and-volcanic-stone-table-made-with-explosionwelding/

19. Howarth, D. Janne Kyttanen builds 3D-printed sofa from a minimal mesh [online 16.02.2017]. http://www.dezeen.com/2015/06/02/janne-kyttanen-3d-printed-sofa-so-good-minimal-mesh-spider-web-cocoons/

20. 3D spausdinimo technologijos skatina mokytis darant [online 22.02.2018]. https://www.vgtu.lt/ universitetas/naujienos/3d-spausdinimo-technologijos-skatina-mokytis-darant/26671?nid=84111

21. Bolderen, G. Exploration of Stability of 3D-Printed Steel Members: A study to buckling behaviour of wire and arc additively manufactured stainless steel tubular columns. Masters thesis. Delft University of Technology, 2017. 38 p.

INFORMATION ABOUT THE AUTHOR:

Linas Krūgelis - PhD of Humanities, Assoc. Profesor at Vilnius Gediminas Technical University, Department of Design; e-mail: Linnarri@yahoo.com Research. Interests: Contemporary architecture, Industrial design, $\mathrm{CAD}$ engineering.

Kopsavilkums. Trīsdimensionālā drukāšana pastāv jau vairākas desmitgades, un ilgu laiku tiek izmantota industriālā ražošanā un izstrādājumu prototipēšanā, un mūsdienās šĩ strauji progresējošā tehnologiija aizvien efektīvāk iesaistās radošajās sfērās. Tas iedvesmo iespēju un metožu pārvērtēšanu, kā ikviens var radīt, modelēt, mainīt savu dzīvesvidi. Paveras jaunas iespējas pielāgotajā arhitektūras un produktu dizainā.

Raksts analizē esošo situāciju trīsdimensionālās preses sasaisti ar dzīvesvidi pēdējā desmitgadē Rietumu pasaulē. Pētījums izcel jaunas tendences un iespējas arhitektiem un dizaineriem radošumam. No sarě̌ğìtu ǵeometrisko struktūru drukāšanas līdz praktisku izmantošanu produktu izveidē. Raksts atspoguḷ dažādus zinātniskos pētijjumus un nozīmīgas tehnolog̣iskās inovācijas. Tas sniedz iespēju koncentrēet un efektīvi novērtēt industrijas attīstības virzienu un sagaidāmos rezultātus. N̦emot vērā, ka trīsdimensionālā drukāšana arhitektūrā un ainavu arhitektūrā pagaidām nav plaši izmantota, raksts atspoguḷo nesenākos dažādu zinātnieku veiktos eksperimentus, atspoguḷojot ceturtās industriālās revolūcijas tendences.

Pētījumu metodologija balstās vēsturiskos pētījumos, salīdzinoši aprakstošajā un salīdzinošajā metodē. Pētījuma rezultāti rāda, attīstoties trīsdimensiju drukāšanai, arhitektūras un dizaina vide apgūs plašāku mākslinieciskās izpausmes veidu klāstu. 